\title{
VEAL PRODUCTION USING TWO TYPES OF RAISING FRIESIAN CALVES
}

\author{
M.A. Abu El-Hamd, I.L.I. Abdelmeseh, A.M.A. Salama, E.A.S. Khalifa \\ and Enas R.M. Elsedfy
}

Animal Production Research Institute, Agricultural Research Center, Ministry of Agriculture, Dokky, Giza, Egypt

\section{SUMMARY}

Twelve newly born male Friesian calves were assigned into two similar groups. The $1^{\text {st }}$ group was raised on fresh milk (suckling period) plus berseem hay and starter $\left(G 1\right.$, solid feed), while the $2^{\text {nd }}$ group was raised on whole fresh milk only $(G 2)$. The experimental period started in G2 from the third week up to six months of age. Results showed that calves in G2 have significantly higher final live body weight, total gain, average daily gain and relative growth as well as better feed efficiency and feed conversion. Calves in $G 2$ have significantly higher left side carcass weight and hind quarter weight, fore quarter boneless meat weight, empty body weight, carcass weight, produced meat and dressing \%. Meat veal produced from calves in G2 showed significant superiority of general quality, taste, flavor, Juiciness, tenderness, color and higher protein and fat content of Longissimus dorsi muscle compared to calves in G1, but there were no significant differences in economic efficiency between the two groups. It could be concluded that raising Friesian calves raised on fresh milk only produced a high quality veal meat.

Keywords: Veal production, fresh whole milk, solid feed, body weight gain, feed conversion and economic efficiency

\section{INTRODUCTION}

Few years ago a special meat consumers were raised in Egyptian society, they able to pay more money to get a super-type of meat, especially those have healer problems. The United States Department of Agriculture (USDA, 1991) defined veal as a meat from immature bovine which includes calves from several different management systems, bob veal-live weight of less than $68 \mathrm{Kg}$, special fed veal-fed milk or milk replacer diet and marketed, at live weight of $68-181 \mathrm{Kg}$, no-special fed veal: fed a variety of different diets and marketed at live weight $68-181 \mathrm{Kg}$. Concerns have been expressed about certain practices in veal calves which are usually slaughtered before 5 month of age to produce white meat (Le Neindre 1993), most veal calves come from dairy farms and are reared in specialized intensive systems. Traditionally, Friesian calves were slaughtered when they reached about $110 \mathrm{Kg}$ of carcass weight (Ketelaar and Smits, 1991). Calves raised for veal are removed from mothers immediately after birth. They commonly experience the stress of minimal

Issued by The Egyptian Society of Animal Production 
colostrums or first milk intake (Reece and Hotchkiss, 1987). No straw or other bedding is provided due to concern that the calves may eat the straw, which would make their flesh darker in color. For the entire raising period, which lasts about 6 month, calves are fed a liquid diet without any provision solid feeds, this type of feeding plan allow the production of carcass and meat with pale color which is one of the main criteria by which market experts and consumers judge veal quality (Miltenburg et al., 1992). Veal and calf carcasses are graded on a composite evaluation of two general grade factors: conformation (proportion of lean, fat, and bone in carcass); and quality of the lean. In addition, the color of the lean carcasses is a key to define between veal, calf and beef carcasses. Typical calf carcasses have a grayish red color of lean meat (USDA, 2001). Special fed veal calves carcass is produced to meet the demands of hotel-restaurant (Kinsman, 1989). Several studies have concentrated on the effect of feeding on veal carcass (Beauchemin and Buchanan-Smith, 1990).

In the new reclaimed land in Egypt, there is no marketing of milk and becomes low in price. So, it an advantage to use this cheap milk in fattening male calves for veal meat production. Therefore the current work was carried out to investigate the effect of fattening calves on fresh whole milk on their growth rate, feed conversion, carcass characteristics and meat quality compared to traditional fattening.

\section{MATERIALS AND METHODS}

This study was carried out at Sakha Animal Production Station, Animal Production Research Institute (APRI), Agricultural Research Center. Twelve newly born male Friesian calves were assigned into two similar groups according to their birth weight. Calves in G1 were given fresh whole milk up to 105 day of age (suckling period) plus starter and berseam hay (solid feeds) from the third week up to 180 day of age. Calves of G2 were raised on fresh whole milk only up to 180 day of age. Calves were fed to cover their requirements according to NRC (1996). The daily feeding scheme during experimental period is shown in Table (1). All calves were given milk in plastic buckets 2 to 5 times daily according to their assigned quantities as shown in Table 2. Calves were fed individually and daily feed intake was adjusted according to body weight change. Mineral blocks were available during the whole experimental period and drinking water was available at all the time. Chemical analysis of feedstuffs used in this experiment are presented in Table (3) and was carried out according to A.O.A.C (1995).

Calves were kept in individual pens, they were moved to loose yard few hours a day. To avoid diarrhea causing gastroenteritis, $30 \mathrm{ml}$ per $25 \mathrm{Kg}$ live body weight from Scourban treatment was introduced orally to the experimental calves two times during the experimental period with two months intervals. Scourban treatment contained sulphadimidine, sulphaguanidine, streptromycin sulphate, neotemycin sulpha and starvuta- Multi-Oligo as commercial feed additives dissolved in fresh milk, also, it contains vitamins A, D3, E, B2, B6, nicotinic acid, folic acid, vitamin $\mathrm{C}, \mathrm{K} 3$, biotin and some minerals (Iron, copper, Zinc, gm/ manganese, cobalt. and cholin). Any noticed diarrhea was treated on time. Calves were weighed biweekly in the morning before drinking and feeding to calculate live daily gain. Relative growth was calculated according to the following formula: (final weight - initial weight / initial weight) X 100 (Abu El-Hamd, 2003). 
Table1. Daily feeding scheme of experimental calves

\begin{tabular}{|c|c|c|c|c|}
\hline \multirow{2}{*}{$\begin{array}{c}\text { Age } \\
\text { (week) }\end{array}$} & \multicolumn{3}{|c|}{ G1 } & \multirow{2}{*}{$\begin{array}{c}\text { G2 } \\
\text { Fresh milk }(\mathrm{Kg})\end{array}$} \\
\hline & Fresh milk (Kg) & Starter(Kg) & Berseem hay (Kg) & \\
\hline 1 & 4.00 & $\begin{array}{ll}--- \\
\end{array}$ & ----- & 4 \\
\hline 2 & 4.00 & ---- & ----- & 4 \\
\hline 3 & 5.00 & 0.250 & 0.125 & 6 \\
\hline 4 & 5.00 & 0.250 & 0.125 & 6 \\
\hline 5 & 6.00 & 0.500 & 0.250 & 7 \\
\hline 6 & 6.00 & 0.500 & 0.250 & 7 \\
\hline 7 & 5.50 & 0.750 & 0.500 & 8 \\
\hline 8 & 5.00 & 0.750 & 0.500 & 10 \\
\hline 9 & 4.00 & 1.000 & 0.750 & 10 \\
\hline 10 & 3.00 & 1.000 & 0.750 & 12 \\
\hline 11 & 2.50 & 1.250 & 1.000 & 12 \\
\hline 12 & 2.00 & 1.250 & 1.000 & 13 \\
\hline 13 & 1.50 & 1.500 & 1.250 & 13 \\
\hline 14 & 1.50 & 1.500 & 1.250 & 13 \\
\hline 15 & 1.00 & 1.750 & 1.500 & 14 \\
\hline 16 & - & 1.750 & 1.500 & 14 \\
\hline 17 & - & 2.000 & 1.750 & 15 \\
\hline 18 & - & 2.250 & 1.750 & 15 \\
\hline 19 & - & 2.500 & 2.000 & 16 \\
\hline 20 & - & 2.600 & 2.000 & 16 \\
\hline 21 & - & 2.850 & 2.250 & 17 \\
\hline 22 & - & 3.000 & 2.250 & 18 \\
\hline 23 & - & 3.250 & 2.500 & 19 \\
\hline 24 & - & 3.450 & 2.500 & 20 \\
\hline
\end{tabular}

Table 2. Number and time of fresh milk diets (Kg) per day offered to experimental calves

\begin{tabular}{cccccc}
\hline Milk quantity & \multicolumn{5}{c}{ Times } \\
\cline { 2 - 6 }$($ Kg) & First & Second & Third & Fourth & Fifth \\
\hline $4-6$ & $7 \mathrm{am}$ & $6 \mathrm{pm}$ & ---- & ----- & ---- \\
$7-12$ & $7 \mathrm{am}$ & $12 \mathrm{am}$ & $6 \mathrm{pm}$ & ------ & ----- \\
$12-16$ & $7 \mathrm{am}$ & $11 \mathrm{am}$ & $3 \mathrm{pm}$ & $6 \mathrm{pm}$ & \\
$16-18$ & $7 \mathrm{am}$ & $11 \mathrm{am}$ & $3 \mathrm{pm}$ & $6 \mathrm{pm}$ & $8 \mathrm{pm}$ \\
\hline
\end{tabular}

Feed efficiency and Feed conversion:

Feed efficiency was calculated according to the following formula:

[(1/DM consumed per Kg gain) x 100] (Krish Mohan et al., 1987). Feed conversion was calculated as: dry matter intake (DMI) / Kg weight gain, crud protein intake (CPI) / Kg weight gain and $\mathrm{Kg}$ total digestible nutrients intake (TDNI)/ Kg weight gain. 
Table 3. Chemical analysis of experimental feed stuffs

\begin{tabular}{cccccccc}
\hline \multirow{2}{*}{ Item } & \multirow{2}{*}{ DM } & OM & CP & CF & EE & NFE & Ash \\
\hline Fresh milk & 12.8 & 94.4 & 24.4 & 00.0 & 30.6 & 39.4 & 5.6 \\
Starter* & 91.3 & 90.3 & 17.0 & 11.9 & 5.0 & 56.4 & 9.7 \\
Berseem hay & 88.3 & 88.3 & 15.3 & 24.2 & 6.1 & 42.2 & 11.7 \\
\hline
\end{tabular}

*The starter feed used in this study was composed of $37.5 \%$ yellow corn, $20 \%$ soybean meal, $15 \%$ corn gluten, $22.5 \%$ wheat bran, $3 \%$ molasses, $0.5 \%$ premix and $1.5 \%$ common salt.

\section{Carcass characteristics:}

At six months of age, three calves from each group with average of $150 \mathrm{Kg}$ live body weight were slaughtered for carcass and meat evaluation. Calves were fasted 18 hrs before slaughter (Sharawy, 2005), each carcass was split into two divisions, each one was divided into fore and hind quarters between 11 and 12 ribs, each quarter was weighed, boneless meat was also calculated. Dressing percent (\%) and boneless meat for each carcass were estimated according to the following formulas:

Dressing percent $(1)=$ carcass weight $/$ fasting weight $\times 100$

Dressing percent $(2)=$ carcass weight / empty body weight $\mathrm{x} 100$

Dressing percent $(3)=$ carcass weight $+($ liver + heart + kidnies $) /$ fasting weight X100

Dressing percent $(4)=$ carcass weight $+($ liver + heart + kidneys $) /$ empty body weight $\mathrm{x}$ 100

Boneless meat $\%(1)=$ meat weight $/$ carcass weight $\times 100$

Boneless meat \% (2) = meat weight + edible offal's / carcass weight $\times 100$

Edible offal $=$ liver + kidney + heart

Samples of $9-10-11^{\text {th }}$ ribs were weighed cold (after $24{ }^{\circ} \mathrm{C}$ ). The eye muscle area were measured by a planiymeter from tracing taken on the cut surface over $9^{\text {th }}$ rib, these samples were taken for chemical analysis and estimate meat quality. The $\mathrm{pH}$ values of meat were measured using $\mathrm{pH}$ meter according to Aitken et al. (1962). Chemical analysis of feedstuffs and meat samples DM contents were all analyzed according to the official methods of the A.O.A.C. (1995).

\section{Meat quality:}

Desired Taste, flavor, juiciness, color and tenderness of cooked meat were performed by ten members in Sakha Animal Production Research laboratories according Chambaz, et al. (2003) using a ten point scale.

General meat quality was calculated according the following formula

General meat quality $=($ Taste grade + flavor grade + juiciness grade + tenderness grade + color grade) / 5

Economic evaluation was calculated as reported by Gaafer (2001) as follow:

Economic efficiency $=($ Price of " 1 " Kg live body weight $) /($ feed cost $/ \mathrm{Kg}$ gain $)$.

\section{Statistical analysis:}

Data obtained in this study were statistically analyzed according to T-test models procedure adapted by SPSS (1997). 


\section{RESULS AND DISSCUSSION}

Growth performance of experimental calves as measured by final weight, total gain, daily gain and relative growth were significantly higher in G2 than those of G1 as shown in Table (4). The superiority of productive performance in calves raised in G2 may be due to the higher biological values of milk or to the easy digestion and absorbance of fresh milk. Bray et al. (1959) came to similar results while Labussiere et al. (2009) and Suarez et al. (2006) indicated that feeding calves on liquid or solid feeds did not affect live body weight and daily gain, while Cozzi (2002) found that final weight and daily gain depended on the type of solid feeds when compared with calves raised on liquid feeds.

Dry matter intake, TDNI and CPI/ Kg weight gain was significantly lower $(\mathrm{P}<0.01)$ in $\mathrm{G} 2$ compared with in G1. From results in Table (4) it could be calculated that $\mathrm{Kg} \mathrm{DMI} / \mathrm{Kg}$ weight gain in G2 was about $25 \%$ of DMI $/ \mathrm{Kg}$ weight gain in G1, $\mathrm{Kg}$. TDNI $/ \mathrm{Kg}$ weight gain in $\mathrm{G} 2$ about $55 \%$ of $\mathrm{Kg}$ TDN $/ \mathrm{Kg}$ weight gain in $\mathrm{G} 1$ and $\mathrm{Kg}$. CPI $/ \mathrm{Kg}$ weight gain in $\mathrm{G} 2$ was about $65 \%$ of $\mathrm{Kg}$ CPI $/ \mathrm{Kg}$ weight gain of $\mathrm{Kg} \mathrm{CPI}$ $/ \mathrm{Kg}$ weight gain in $\mathrm{G} 1$.

General, DMI, TDNI and CPI/Kg weight gain were improvement in G2 compared with in G1 (Table 4).

Table 4. Means $(\mathrm{X} \pm \mathrm{SE})$ of growth performance, feed conversion, feed efficiency and relative growth of Friesian calves raised on two types of feeding

\begin{tabular}{lccc}
\multicolumn{1}{c}{ Item } & G1 & G2 & Sign. \\
\hline Growth performance: & & & \\
Initial weight (Kg) & $31.6 . \pm 0.8$ & $30.8 \pm 0.7$ & NS \\
Final live body weight (Kg) & $144.6 \pm 3.7$ & $168.8 \pm 3.4$ & $* * *$ \\
Total gain (Kg) & $113.0 \pm 4.0$ & $138.0 \pm 3.7$ & $* * *$ \\
Daily gain (Kg) & $0.628 \pm 0.022$ & $0.768 \pm 0.02$ & $* * *$ \\
Relative growth (\%) & $359.9 \pm 20.8$ & $449.8 \pm 19.0$ & $* *$ \\
Feed conversion: & & & \\
Kg DMI / Kg weight gain & $6.499 \pm 0.140$ & $1.670 \pm 0.128$ & $* * *$ \\
Kg TDN / Kg weight gain & $3.864 \pm 0.093$ & $2.156 \pm 0.085$ & $* *$ \\
Kg CPI / Kg weight gain & $1.082 \pm 0.028$ & $0.707 \pm 0.025$ & $* * *$ \\
Feed efficiency: & & & \\
Weight gain (Kg) / Kg DMI & $15.446 \pm 1.413$ & $60.078 \pm 1.29$ & $* * *$ \\
Weight gain (Kg) / Kg TDNI & $25.914 \pm 2.725$ & $49.555 \pm 2.487$ & $* *$ \\
Weight gain (Kg) / Kg CPI & $92.782 \pm 4.068$ & $142.026 \pm 3.714$ & $* *$ \\
\hline
\end{tabular}

NS not Significant $\quad * *$ Significant at $\mathrm{P}<0.01 \quad * * *$ Significant at $\mathrm{P}<0.001$

Results in Table (4) indicated that raising veal calves in G2 on fresh milk elevate significantly higher weight gain /Kg DMI, TDNI and CPI comparing with G1. Calves in G2 weight gain $/ \mathrm{Kg}$ DMI was about $388 \%$ of that obtained in G1, weight gain $/ \mathrm{Kg}$ TDNI in G2 was about $190 \%$ of that found in G1 and weight gain /Kg CPI in G2 was about $153 \%$ of that obtained in G1, similar results were obtained by Cozzi et al, (2002).

\section{Carcass component:}

Weights of different carcass divisions and their percentages from left side carcass weight are shown in Table (5). It was found that calves in G2 had significantly higher weights of left side, fore quarter, hind quarter, fore quarter boneless meat and hind quarter boneless meat compared to that of calves in G1. On the other hand, related to 
percentages of fore quarter weight per left side carcass weight and hind quarter weight per left side carcass weight were insignificant. Bray et al. (1959) came to similar results regarding to hind quarter.

Table 5. Means $(\mathrm{X} \pm \mathrm{SE})$ of carcass component percentages $(\%)$ of each of for quarter and hind quarter relative to left side of carcass weight

\begin{tabular}{lcccc}
\multicolumn{1}{c}{ Items } & G1 & G2 & MSE & Sign. \\
\hline Left side carcass weight $(\mathrm{Kg})$ & 36.67 & 44.50 & 1.18 & $* * *$ \\
Fore quarter weight $(\mathrm{Kg})$ & 17.83 & 21.50 & 0.62 & $* * *$ \\
Hind quarter weight $(\mathrm{Kg})$ & 18.83 & 23.0 & 0.59 & $* * *$ \\
Fore quarter boneless meat weight $(\mathrm{Kg})$ & 12.17 & 15.33 & 0.56 & $* *$ \\
Hind quarter boneless meat weight $(\mathrm{Kg})$ & 13.50 & 16.05 & 0.4 & $* *$ \\
Fore quarter weight/left side carcass weight x 100(\%) & 48.6 & 48.3 & - & NS \\
Hind quarter weight/left side carcass weight x 100(\%) & 51.4 & 51.7 & - & NS \\
\hline
\end{tabular}

NS not Significant $\quad * *$ significant at $\mathrm{P}<0.01 \quad * * *$ significant at $\mathrm{P}<0.001$.

\section{Carcass characteristics:}

Average empty body weight for calves in G2 was significantly higher than that weight of calves in G1 (Table 6). Similarly, carcass weight in G2 was significantly higher than that obtained in G1, indicating that calves in G2 produced significantly more lean than that produced from calves in G1, Boneless meat, and eye mussel area (cm2) was not significantly affected by the raising method of suckling calves. Dressing percentages (1a and 1c) were significantly higher in calves of G2 compared with calves in G1. This may be due to that the calculation of dressing percent by way of number 3 represents more real and more accurate carcass case. This is in harmony with the results of Cozzi et al. (2002) who reported insignificant differences in carcass weight and dressing percent when calves were raised on solid or liquid feeds, while, empty body weight was heavier in calves G2 comparing with those calves in G1.

\section{Meat quality:}

Results in Table (7) indicated that calves in G2 produced an significantly desirable meat taste, meat flavor, meat juiciness, meat tenderness and meat color comparing with meat produced from calves in G1, it have a lower grades, when cooked in water. Cozzi et al. (2002) found that the difference in color meat, between meat obtained from calves raised on milk and solid deeds or raised on fresh milk only depend on the type of used solid feeds, referring to tenderness, flavor and juiciness they stated insignificant difference between meats obtained from calves raised on milk and solid feeds or fresh milk only.

General meat quality represents the ability of consumers towered special type of meat, results estimated in Table (7), shows that meat consumers used in the study prefer meat produced from veal calves of G2 regardless cooking, Johnson et al. (1992) came to similar results, the authors found that calves fed whole milk diet had lighter more youthful lean color.

\section{Chemical characteristics:}

Chemical analysis of meat produced from Longissimus dorsi muscle of calves in G2 revealed significantly higher dry matter $(27.2 \%)$ and protein $(89.8 \%)$ compared to calves in G1 (24.9 and 88.8\%, respectively). On the other hand, intramuscular fat was lower in G2 $(6.8 \%)$ than in G1 $(7.8 \%)$, however, ash was the same in both groups 
(3.7\%). Bray et al. (1959) came to similar results while, Cozzi et al. (2002) stated insignificant difference in chemical composition of meat from calves raised on milk and solid feeds or fresh milk only.

Table 6. Means $(\mathrm{X} \pm \mathrm{SE})$ of carcass and lean weight, percentage (\%) of Boneless meat, dressing percent (\%) and eye mussel area

\begin{tabular}{|c|c|c|c|c|}
\hline \multicolumn{2}{|l|}{ Items } & G1 & G2 & Sign. \\
\hline Empty body weight & $(\mathrm{Kg})$ & $117.4 \pm 3.46$ & $143.3 \pm 3.46$ & $* *$ \\
\hline Carcass weight & $(\mathrm{Kg})$ & $73.33 \pm 2.36$ & $89.00 \pm 2.53$ & $* * *$ \\
\hline Lean & $(\mathrm{Kg})$ & $51.33 \pm 1.85$ & $63.67 \pm 1.85$ & $* * *$ \\
\hline Boneless meat $\%$ & (1) & $70.0 \pm 0.63$ & $71.5 \pm 0.64$ & NS \\
\hline Boneless meat $\%$ & (2) & $75.8 \pm 0.67$ & $76.2 \pm 0.67$ & NS \\
\hline Dressing $\%$ & (1a) & $49.5 \pm 0.34$ & $53.1 \pm 0.34$ & $* *$ \\
\hline Dressing\% & (1b) & $62.1 \pm 0.71$ & $62.1 \pm 0.71$ & NS \\
\hline Dressing\% & (1c) & $52.4 \pm 0.14$ & $55.8^{\mathrm{b}} \pm 0.14$ & $*$ \\
\hline Dressing\% & (1d) & $66.0 \pm 0.31$ & $65.0 \pm 0.31$ & NS \\
\hline Eye mussel area & $\left(\mathrm{Cm}^{2}\right)$ & $70.8 \pm 2.80$ & $72.8 \pm 2.80$ & NS \\
\hline $\begin{array}{l}\text { NS not Significant } \\
\text { (1) }=\text { meat weight } / \text { carce } \\
\text { (1a) }=\text { Carcass weight } \\
\text { (1c) }=\text { Carcass weight }+ \\
\text { (1d) }=\text { Carcass weight }+\end{array}$ & $\begin{array}{l}\text { Significar } \\
\text { s weight } \\
\text { asting we } \\
\text { Liver +hed }\end{array}$ & $\begin{array}{l}.05 \quad * * \text { Signi } \\
(2)=\text { meat } \mathrm{w} \\
00 \quad(1 \mathrm{~b})=\mathrm{Ca} \\
\text { nies }) / \text { Fasting } \mathrm{b} \\
\text { nies) / Empty b }\end{array}$ & $\begin{array}{l}0.01 \quad * * * \mathrm{Si} \\
\text { ble offal / carca } \\
\text { t / Empty body } \\
\text { x100 }\end{array}$ & $\begin{array}{l}\mathrm{tP}<0.00 \\
100 \\
100\end{array}$ \\
\hline
\end{tabular}

Table 7. Means $(\mathrm{X} \pm \mathrm{SE})$ of some meat quality cooked by two methods

\begin{tabular}{lcccc}
\hline \multicolumn{1}{c}{ Items } & G1 & G2 & MSE & Sign. \\
\hline Taste & 7.1 & 8.5 & 0.2 & $* * *$ \\
Flavor & 6.8 & 8.9 & 0.3 & $* * *$ \\
Juiciness & 5.9 & 8.8 & 0.3 & $* * *$ \\
Tenderness & 6.6 & 9.0 & 0.2 & $* * *$ \\
Color & 6.8 & 8.6 & 0.3 & $* * *$ \\
General meat quality & 6.6 & 8.8 & 0.3 & $* *$ \\
\hline ** Significant at $\mathrm{P}<0.01$ & $* * *$ Significant at $\mathrm{P}<0.001$ & &
\end{tabular}

Economic efficiency:

Table (8) shows that feed cost of one kilogram of meat obtained from calves in G2 was higher than that of calves in G1. On other hand, return of daily gain was higher in G2 than in G1. Price of one Kg was higher in G2 (26 L.E, 144\%) than in G1 (18 L.E, 100\%). Meanwhile, there was no significant difference between G1 and $\mathrm{G} 2$ regarding the economic efficiency.

Table 8. Effect of raising method in suckling Friesian calves on economic efficiency

\begin{tabular}{lccc}
\hline \multicolumn{1}{c}{ Item } & G1 & G2 & Sign. \\
\hline Daily feed cost (L.E.) & 8.04 & 15.21 & $* * *$ \\
Return of daily gain (L. E.) & 11.034 & 19.2 & $* *$ \\
Feed cost (L.E)/ Kg gain & $12.8 \pm 0.43$ & $19.8 \pm 0.40$ & $* *$ \\
Economic feed efficiency (\%) & $137.24 \pm 15.2$ & $126.33 \pm 13.9$ & NS \\
\hline NS no significant ** Significant at P<0.01 & $* * *$ Significant at P<0.001 \\
Price of one Kg weight gain was 18 L.E in G1 and 26 L.E in G2, Price of CFM was 1850 L.E/ton \\
$\begin{array}{l}\text { Price of berseem hay was 600 L.E/ton } \\
\text { Price of Kg milk was 1.30 L.E/Kg }\end{array}$
\end{tabular}


Finally, the results obtained in this study showed that, veal calves fed fresh milk only had higher body weight gain, feed conversion and efficiency and better carcass traits and meat quality compared with calves fed milk and solid feeds.

\section{REFERENCES}

A.O.A.C., 1995. Official Methods of Analysis, Association of Official Chemists, Washington, USA

Abu El-Hamd, M.A., 2003. Rumenal development in suckling calves fed protected fat and protected protein. Ph.D. Thesis, Fac. Agric. Mansoura Univ. Egypt.

Aitken, A., J.C. Casey, I.F. Penny and C.A. Voyls, 1962. Effect of drying temperature in the accelerated freeze drying of pork. J.Sci. \& Fd.Agric., 13, 439.

Beauchemin K.A. and J.G. Buchanan-Smith, 1990. Effects of Fiber Source and Method of Feeding on Chewing Activities, Digestive Function, and Productivity of Dairy Cows. J. Dairy Sci., 73, 3:749-762.

Bray, R.W., E.H. Rupnow, M. Flora, N.N. Hanning, Allen and R.P. Niedermeier, 1959. Effect of Feeding Methods on Veal Production and Carcass Quality. II. Carcass Grades, Liver, Hide, Specific Gravity, Yield and Chemical Analysis of the Muscle. J Anim Sci. 18: 732-737

Chambaz, A., M.R.L. Scheeder, J.M. Salman and P.A. Dufey, 2003. Meat quality of Angus Simmental, Chrolais and Limosin steers compared at the same intaramuscular fat content. Meat Sci.63: 491-500.

Cozzi, G., F.Gottardo, E. Mattielb, E. Canali, M.Verga Scanzidnim, and I. Andrighetto, 2002. The provision of solid feeds to veal calves: 1-Growth performance, fore stomach development, cacass and meat quality. J. Animal sci. 80: 357-366.

DC. Reece WO and DK. Hotchkiss, 1987. Blood studies and performance among calves reared by different methods. J. Dairy Sci;70:1601-1611.

Gaafar, H.M.A, 2001. Performance of growing calves fed rations containing corn silage. Ph.D. Theses, Fac. Of Agric., Kafer Elsheikh, Tanta Univ. Fd. Technology. 4 (9): 366-369.

Grau, R. and F. Hamm, 1957. Uber des Waasser binding Overmagen de Muskels, Zeitsahrift Fur bebananittal untor, Untercucining Und Fercining 105, 6, 446-460.

Johnoson, D.D., H.H. Van Horn, R.L. West and B Jr. Harris, 1992. Effect of calf management on carcass characteristics and platability of veal calves J. Dairy Sci. 75: 2799-2804.

Ketelaar, C.C., and A.C. Smits, 1991. Spatial requirements of individually housed veal calves of 175 to $300 \mathrm{Kg}$. In: J.H.M. Metz and C. M. Groenestein (Ed.) New Trends in Veal Calf Production. Proc. Int. Symp. on Veal Calf Production. pp 4953. EAAF' Publications, Pudoc, Wageningen, The Nether- lands.

Kinsman R., 1989. A Conductive Education Approach to Stroke Patients At Barnet General Hospital. Physiotherapy, Volume 75, Issue 7, Pages 418-421.

Krishna Mohan, D.K; K.K. Krishna Reddy and A.S. Srirama Murthy, 1987. Protein requirements of crossbred lambs. Ind. J Anim. Sci., 50 (10): 1121-1127.

Labussiere, E., S. J. Bertr Dnbois, G. Van Milgen and J. Noblet, 2009. Effect of solid feed on energy and protein utilization in milk-fed veal calves.

Le Neindre, P., 1993. Evaluating housing systems for veal calves. J Anim Sci. 71:1345-1354. 
Miltenburg, G.A.J., T.H. Wensing, F.J.M. Smulders, and. H.J. Breukink, 1992. Relationship between blood hemoglobin, plasma and tissue iron, muscle heme pigment and carcass color of veal .J. Anim. Sci. 70:2766-2772.

NRC, 1996. Nutrient Requirements of Domestic Animals. Nutrient Requirements of Cattle. 7th ed. Natl. Acad. Press, Washington,

Sharawy A.M., 2005. Effect of some feed additives on fattening and carcass characteristics of Friesian calves. M. Sc. thesis, Fac. of Agriculture, Moshtohor, Zagazig Uuniv., Banha branch.

SPSS for Windows, 1997. Statistical package for the social science, Release 6, SPSS, Inc. Chcago, USA

Suarez, B.J., C.G. Van Reenen, G. Beldman, J. Van Delen, J. Dijkestra and W.J.J. Gerrits, 2006. Effect of supplementing concentrate differing in carbohydrate composition in veal calve diets: Animal Effect of supplementing concentrate differing in carbohydrate composition in veal calve diets: Animal performance and rumen fermentation characteristics. Dairy Sci. 89: 4365-4375.

USDA, 1991. United States Department of Agriculture Printing Office. Milk: Production, Disposition, and Income. 1(91). Washington, D.C.

Volovinskaia, V.R. and B.Y Merkolova, 1959. Modification of the water holding capacity method of meat. Fd. Industry. Vol. 11, 80 (Moscow). 
إنتاج لحم البتلو باستخدام طريقتين مختلفتين لتنشئة العجول الفريزيان الرضيعة

محمد عوض أبو الحمد، إبراهيم لويس إبراهيم عبد المسيح، أحمد محمد أحمدٍِّلامة، إيمـان أحمد سيا خليفة، إيناس رمزى محمد الصدفى إير الصير

مركز البجوث النراعية، معطج بحوث الاتتاج الحيوانى، الدقى، الجبزة، مصر

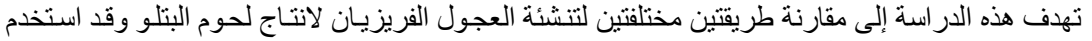

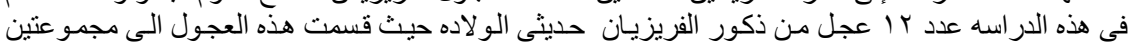

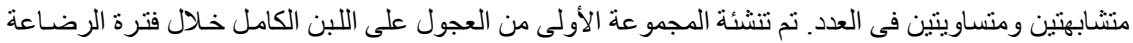

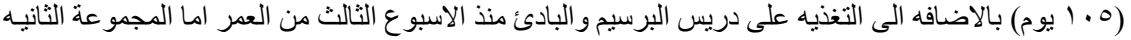

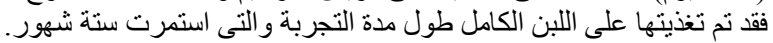

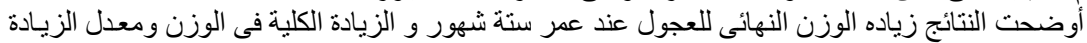

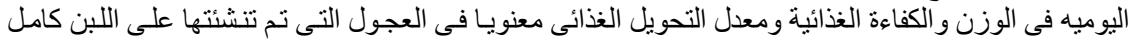

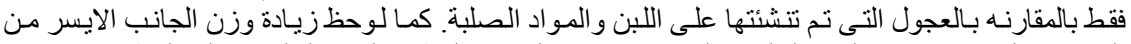

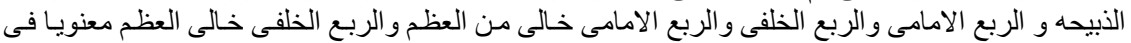

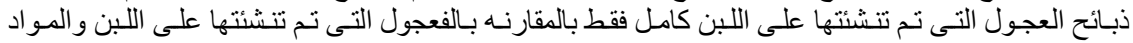

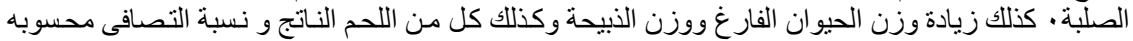

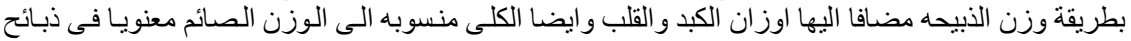

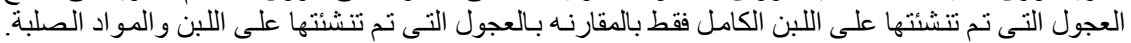

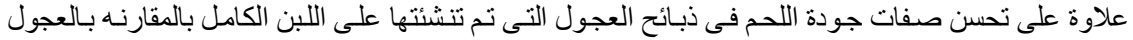

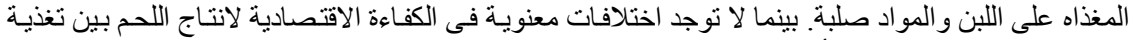
العجول على اللبن الكامل فقط أو اللبن و المواد الصلبة. 